to older minds than mine, beyond the banks of Newfound. land.

But we see, from all that has been said, the vast importance of noting the colours of the clouds. We depend much in this country on the colour of the clouds for weather prediction. Ice, however, at this time of year, by refrigerating the atmosphere, often interferes with calculation.

Hailer Grace, Newfoundland

H. C.

\section{THE PROGRESS OF EVOLUTION}

THE new journal mentioned below is edited jointly by Dr. Otto Caspari, of Heidelberg, Prof. Dr Gustav Jäger, of Stuttgart, and Dr. Ernst Krause (Carus Sterne), of Berlin; and on the list of its contributors are the names of Charles Darwin, Emst Haeckel, Friedrich von Hellwald, and many others whose scientific creed is Darwinism.

The editors in their iniroductory statement say that a new day has dawred for natural science, since our great countryman applied the natural laws which govern the whole universe to the phenomena of the development of life, and showed the fallacy of assigning that central position in nature to man himself which had been attributed to him for ages, as Copernicus did in the case of our planet three centuries ago. Man, who seemed to stand above nature hitherto has, without being drawn down from his eminent position, been incorporated with nature as one of her integral parts. The new monistic philosophy caused a wonderful reaction, and an animated reciprocal intercourse arose between the subjective and objective sciences. All the sciences which treat of man, from anthropology, ethnology, and the psychology of peoples, to the history of culture and states, national economy, the philosophy of law, history, and religion, and the sciences of morals and dietetics, proved to be natural sciences quite as much as mineralogy, biology, the practical education of man, and the cultivation of plants and animals.

The result of this general intercourse of the different sciences, has been a continued and encouraging confirmation of the monistic principle contained in the theories of descent and development; the literature, however, which was generated by the reaction, is dispersed and can be collected only from the various scientific journals. Thus, a general desire for collection and concentration has sprung up amongst all those who look upon the theory of development as a considerable progress of the human mind.

The new Kosmos will bring together what has hitherto been unconnected; will point out the gaps still existing, and thus lead to their being speedily filled; will reduce contrasts and contradictions to their true nature, and will oppose pernicious dogmatism. Kosmos will, with regard to the special domains of natural science, bear a certain critical and polemical stamp, its editors being aware that even science is best developed and strengthened in the fight for its existence, and that in the end the "fittest" theory will survive. All articles in the new serial are written in popular language, and are inended for a large circle of readers.

The first number contains a series of very interesting articles, of which we may mention-Philosophy and its Union with Natural Science, by Otto Caspari.; On Inheritance, by Dr. Gustav Jäger; On Modern Anthropology, by the same; On the Chronicles of the History of Development, by Ernst Haeckel; The History of Creation and Chorology two Centuries ago, by Carus Sterne; On the Significance and Objects of Ethonography, by Friedrich von Hellwald; and an excellent review of Darwin's work on Cross and Self-Fertilisation, by Dr. Hermann Müller.

I Kosmos; Zeitschrift fïr eintheitliche Weltcwschaunus auf Grund der Entwickelingslehre. (1 Heft, April, 1877.)

\section{ENGINEERING EDUCATION IN $7 A P A N$}

THE technical education of engineers is a subject which has engaged public attention for a long time past and is one of great national importance. It is somewhat singular that this country, foremost as it has always been in matters of engincering enterprise, should be so behindhand in the systemasic education of its engineers, there being no establishment in England devoted to that object which is recognised by the profession. Under the system that has been in vogue up to a comparatively recent period a youth intended for an engineer is taken from school at the age of sixteen being thereby deprived of the most valuable years of his education, and placed in some engineering manufactory, where he remains, perhaps, till he is twenty. In those four years his so-called "training" consists in going through the manual routine of the various workshops and "picking up" what knowledge he can by keeping his eyes open and living on good terms with the workmen. His last year is usually spent in the drawing-office, where, by a similar process of "picking up," he learns how to draw if not to design machinery or works of construction. At the end of that time his education is supposed to be complete, and he either remains as a draughtsman until something better is offered him, or he enters the office of another engineer for the purpose of improvement. All this time the far more important theoretical training is neglected altogether, no classes or examinations are held, no lectures or other instructions are given, and though some few energetic young men in some way make up this loss by private study they are a great exception, and the hours of manual work are usually so heavy (from 6 A.M. till 5 P.M.) as to render working in the evening both fatiguing and unprofitable.

The Continental system goes to the other extreme, teaching the theory and discarding the practice. This system is as bad as the other, for experience has shown that in engineering works a practical man without scientific training seldom makes such serious blunders as a scientific man without practical experience. It can only be by a judicious combination of the two systems, allowing science and practical experience to work hand in hand together in the education of an engineer that the best results can be looked for, and in these days of close competition, not only between man and man, but between country and country, it is of the utmost importance to a nation that its engineers should be instructed upon the best and soundest principles. The Indian Government recognised this when it established the Royal Indian Engineering College at Cooper's Hill for the systematic training of engineers for the Public Works Department of India; and it is remarkable that the profession of engineering should stand alone in England as having no recognised Alma Mater of its own. Many years ago an engineering college was established at Putney upon a good system, but it was badly managed, and after becoming a nuisance to the neighbourhood, was ultimately shut up; at the present time, with the exception of the technical classes at the Crystal Palace and at King's College, which, in a small way, are doing good work, there is no institution in this country devoted to the education of engineers.

While England is so far behindhand in this important question, a great work has been done by the Japanese Government in the establishment of an Imperial College of - Engineering at Tokei, an institution which "gives to its students a highly scientific training, combined with actual practical experience in engineering workshops which give employment at the present time to over three hundred workmen; but which are being largely increased and are turning out all classes of engineering
work. 
The system adopted is as follows:-- The course of training extends over six years. The furst two years are spent entirely at college; during the next two years, six months of each year are spent at college and six months in the practice of that particular branch which the student may select; the last two years are spent entirely in practical work. The system of instruction in the college is partly professorial and partly tutorial, consisting in the delivery of lectures and in assistance being given to the students in their work.

Candidates for admission must be Japanese subjects under the age of twenty, and must p zss a preliminary examination, the best fifty being chosen as cadets, of which there are two classes. A student may elect to enter either as a Government cadet - in which case all his expenses are defrayed by Government, under whom he binds himself to serve for seven years at the expiration of his six years' training-or he may enter as a private cadet, paying his own expenses, in which case the obligation to serve subsequently under Government is dispensed with. In all other respects he is on the same footing as the Government cadet.

The whole system of training may be divided into three courses:-(I) General and Scientific, (2) Technical, and (3) Practical. The general and scientific course, which is taught during the first two years, includes (1) English language and composition, (2) geography, (3) clementary mathematics, (4) elementary mechanics, (5) elementary physics, (6) chemistry, and (7) mechanical drawing.

The Technical course consists of the following branches of engineering:-(1) Civil engineering, (2) mechanical engineering, (3) telegraphy, (4) architecture, (5) chemistry and metalurgy, and (6) mining. This course is taught during the third and fourth years of the curriculum. The practical course, in which the students are engaged auring, the last two years in the practice of the special branct. each may have selected, consists of working in the laboratories of the college, and in the engineering works connected with it established at Akabane, where they serve a regular engineering apprenticeship. While this course is going on lectures on special subjects are given, and the students are required to prepare reports upon the work in which they have been engaged.

In the Technical course are included the higher mathematics and natural philosopky, engineering, civil and mechanical, geology, mineralogy, surveying, naval architecture, strength of materials, practice in the chemical, physical, metallurgical, and engineering laboratories, and in the drawing office and workshops.

The main building, which is a very handsome structure, consists of a central portion containing the large examination hall and library, drawing offices and class rooms, and on each side of this extends a wing containing other class rooms and lecture halls. This is the College proper, and surrounding it are separate buildings set apart for the dormitories, Professors' houses, museum and laboratories of which there are four devoted respectively to chemistry, physics, metallurgy, and engineering. The buildings have been very admirably arranged by the Principal of the College, Mr. Henry Dyer, C.E., and the architectural details have been carried out with great skill by Mr. C. A. de Boinville.

The staff of the College consists of a Principal and nine English Professors, assisted by Japanese teachers, and the Institution is under the jurisdiction of the Minister of Public Works.

A calendar of the College is published annually, which contains information relative to the admission of students, courses of study, and examination papers, as well as catalogues of the splendid collection of instruments in the laboratories, and of the books in the library, which seems to be exceptionally rich in almost every branch of greneral and scientific literature.

SUSIECTED REEATIONS BETWEEN THE SUN AND EARTII

\section{III.}

$N$ the first of these articles I tried to show that the magnetism of the earth is affected by the state of the sun's surface. I shall now try to show that the meteorology of the earth is likewise affected by the same cause.

Mr. Baxendell, of Manchester, was, I think, the first to point out that the meteorological convection currents of the earth appear to vary according to the state of the sun's surface. More recently Mr. Meldrum, of the Mauritius Observatory, has brought this connection very forcibly before us by showing, from the results of his observations, that there are more cyclones in the Indian Ocean during years of maximum than during years of minimum sun-spots. This will be seen from the following table :--

\section{TABLE II.}

Comparison of the Yearly' Namber of Cyclows occurring in the Indian Ocean with the Leariy Number of Sposs on the Sinn.

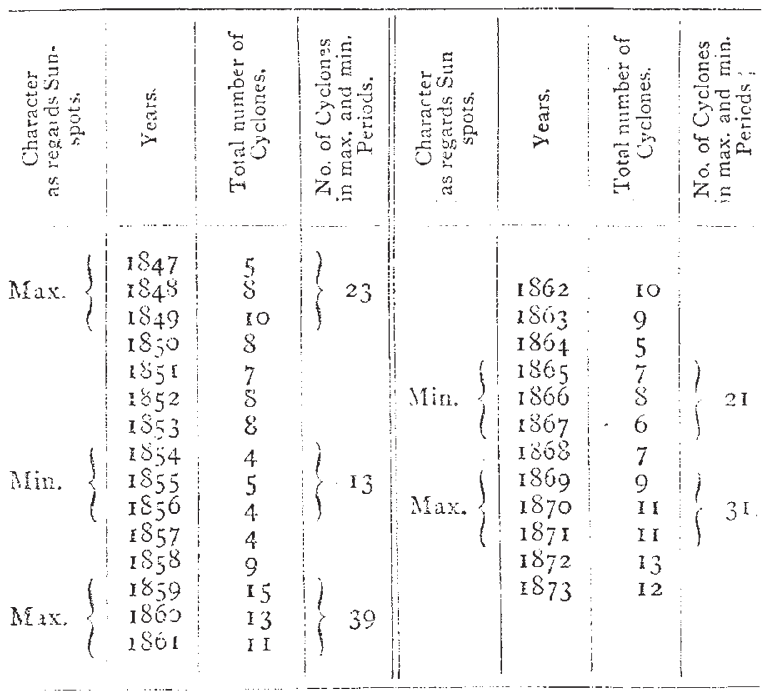

Prof. Poey has confirmed this conclusion of Mr. Meldrum by showing that there is a similar periodicity as regards the cyclones which make their appearance off the coast of Central America.

In the next place Dr. Arthur Schuster has found that the years of minimum sun-spots coincide very nearly with the good wine years in Germany. This will appear from the following table.

\section{TABLE III.}

Exhibiting the near Coincidence between the Years knowen as good Wine Years in Germany and the 'Years of minimum Sun-spots.

Dates of Minim im
Sun-spots.
1784.8
1798.5
1810.5
1823.2
1833.8
1844.0
1856.2
1867.2

Years known in Germany

$$
1784
$$

(?)

1822

1834

1846

$\{1857$

$\left\{\begin{array}{l}1858 \\ \text { I } 868\end{array}\right.$

Again, it has quite recently been remarked by $\mathrm{Dr}$. Hunter, Director-General of Statistics to the Government of India, that the famines in Southern India have a period of recurrence which is nearly eleven years, being thus of the same duration as that of sun-spot frequency. 